\title{
Light microscopy and surface topography of Urotrema scabridum and Renschetrema indicum (Digenea) from Rhinopoma hardwickii (Chiroptera): first report in Egypt
}

Microscopia de luz e topografia superficial de Urotrema scabridum e Renschetrema indicum (Digenea) de Rhinopoma hardwickii (Chiroptera): primeiro relato no Egito

Kareem Morsy ${ }^{1,2 *}$; Fathy Abdel-Ghaffar ${ }^{2}$; Abdel-Rahman Bashtar²; Saad Bin Dajem ${ }^{1}$; Rewaida Abdel-Gaber ${ }^{2,3}$; Marwa Mostafa ${ }^{2}$

${ }^{1}$ Biology Department, College of Science, King Khalid University, Abha, Saudi Arabia

${ }^{2}$ Zoology Department, Faculty of Science, Cairo University, Giza, Egypt

${ }^{3}$ Zoology Department, College of Science, King Saud University, Riyadh, Saudi Arabia

Received March 8, 2018

Accepted April 18, 2018

\begin{abstract}
This report introduced the description of two different species of digenean parasites isolated from the intestine of Rhinopoma hardwickii with new host and locality records in Egypt. The recovered helminthes were studied morphologically and morphometrically by light microscopy and the surface topography of the two species was elucidated by scanning electron microscopy (SEM). Urotrema scabridum had an elongated body, testes were tandem, ovaries were pretesticular, and vitelline follicles were observed in 2 lateral fields. SEM showed that the anterior half was covered with random and backwardly directed tegument spines. The lumen of the oral sucker was as a longitudinal slit encircled with type I dome-shaped papillae. The ventral sucker was wrinkled and covered by tongue-shaped tegument spines and several scattered papillae. Renschetrema indicum had a fusiform body with minute spines densely distributed in the anterior part of the body; testes sub-triangular, ovary fusiform; vitellaria were randomly distributed around the ceca and genital organs. SEM showed that the fore-body was ventrally concave and surrounded by cytoplasmic ridges equipped with numerous closely packed claw-shaped spines. The oral sucker was externally surrounded by two circles of papillae while the lip of the ventral sucker was rounded and surrounded by three papillae located in its upper end and anterolaterally.
\end{abstract}

Keywords: Urotrema scabridum, Renschetrema indicum, Rhinopoma hardwickii, surface topography, ultrastructure, light microscopy, bats.

\section{Resumo}

O trabalho descreve duas espécies diferentes de parasitas digêneos isolados do intestino de Rhinopoma hardwickii, com novos registros de hospedeiros e localidade no Egito. Os helmintos recuperados foram estudados morfologicamente e morfometricamente por microscopia óptica, e a topografia superficial das duas espécies foi verificada por microscopia eletrônica de varredura (MEV). Urotrema scabridum apresenta um corpo alongado, testículos em tandem, ovários localizados pré-testiculares e os folículos vitelinos foram observados em 2 campos laterais. A microscopia eletrônica (ME) mostrou que a metade anterior do tegumento estava coberta com espinhos aleatoriamente e voltados para trás. O lúmen da ventosa oral apresentava-se como uma fenda longitudinal cercada de papilas em forma de cúpula tipo I. A ventosa ventral estava enrrugada e coberta por espinhos no tegumento em forma de língua e com várias papilas dispersas. Renschetrema indicum tinha um corpo fusiforme com espinhos diminutos densamente distribuídos na parte anterior do corpo; testículos sub-triangulares, ovários fusiformes; as glândulas vitelínicas estavam distribuídas aleatoriamente em torno do ceco e dos órgãos genitais. À ME a região anterior mostrou-se ventralmente côncava e cercada por cristas citoplasmáticas equipadas com numerosos espinhos em forma de unhas muito próximos. A ventosa oral apresentou-se externamente cercada por duas fileiras de papilas, enquanto a borda da ventosa ventral mostrou-se arredondada e cercada por três papilas localizadas na sua extremidade superior e antero-lateralmente.

Palavras-chave: Urotrema scabridum, Renschetrema indicum, Rhinopoma hardwickii, topografia de superfície, ultrastructure, microscópio de luz, morcegos. 


\section{Introduction}

The tegument and its microtopographical features, such as papillae, spines and tubercles, are considered to be the major host-parasite interface and the most important taxonomical aspects of adult trematodes (MATA-LÓPEZ \& LEON-REGAGNON, 2006). The tegument is involved in the protection of the parasite against host enzymes and immune systems, the excretion wastes, and the absorption of nutrients (BURTON, 1966; LUMSDEN, 1975; THREADGOLD, 1984; PAPERNA \& DZIKOWSKI, 2006). Electron microscopic techniques, such as scanning (SEM) and transmission electron microscopy (TEM), are of a particular interest in the description of tegumental structures. Indeed, SEM can provide data on the external morphology and localization of these structures, while TEM allows for ultrastructural investigations at a cellular level.

From the parasitological point of view, bats are of a special interest for number of reasons: bats are known to be susceptible to many infections of animals and man. Although each species of bat has its own ecology and behaviour, a remarkable degree of interspecies associations occurs. These associations provide a good opportunity for the transmission of certain parasites between individuals of different species of bats (WIMSATT, 1970).

Little is known regarding the helminth parasites infecting Egyptian bats, with no available data in the literature since the study of Saoud \& Ramadan (1976); they reported a numerical data on four species of digenean parasites without morphological identification, these were Prosthodendrium sp., Anchitrema sp., Lecithodendrium sp. and Acanthatrium sp. which needs further revision. So, these animals should attract the attention of several parasitologists working in Egypt as recommended by several authors who stated that the helminth fauna of bats in Egypt is fairly rich and nothing was done on the various aspects of the host parasite-relationships, particularly host specificity, the prevalence of parasites and the inter-relationships between members of the parasitic fauna.

The plagiorchioid Urotrematidae Poche (1926) comprises Urotrema Braun (1900), with 7 nominal species; Sinineobucephalopsis; Sinogastromyzontrema and the monotypic Urotrematulum Macy (1933), all of which inhabit mammals and lizards in the Nearctic and Neotropics. The taxonomic status of members of Urotrema is uncertain. Caballero \& Zerecero (1942) recognized only 2 of the 5 nominal species of Urotrema that were known and had been recorded at the time: Urotrema shillingeri Price (1931) in a muskrat Odatra zibthica from Maryland; Urotrema scabridum Braun, 1900 inhabiting mammals; and Urotrema wardi, Perez-Vigueras (1940) inhabiting lizards. Others are Urotrema lasiurensis Alicata, 1932 in the bats Nycteris borealis and Nucteris humeralis from Texas and Maryland, respectively; Urotrema minuta Macy (1933) in the bat Lasionycteris noctivagans from Minnesota; Urotrema aelleni Baer (1957) in Myotis bocagei from the Ivory Coast; Urotrema macrotestis Mane-Garzon \& Telias (1965) in the water rat, Holochilus brasiliensis vulpinus from Uruguay; and Urotrema shirleyae from Norops oxylophus and Norops cupreus from the Area de Conservacion Guanacaste, Costa Rica (ZAMPARO et al., 2005).
Renschetrema species are digeneans of the order Plagiorchiida, family Renschetrematinae Yamaguti, 1971. These trematodes are parasites of vertebrates and are characterized by their pyriform body and the presence of spinose tegument, testis opposite in the hind body, vitellaria posterior to the testis and the uterus confined to the hind body. In the present study, the morphological and morphometric characteristics of two digenetic trematodes isolated from the intestine of the lesser mouse-tailed bat Rhinopoma hardwickii (family Rhinopomatidae) were investigated by light microscopy. Additionally, the surface ultrastructure of the two parasites was observed and compared by scanning electron microscopy.

\section{Materials and Methods}

Ten specimens of the lesser mouse-tailed bat Rhinopoma hardwickii (Chiroptera: Rhinopomatidae) were captured using a mist net from buildings where bats may found in Cairo, Egypt. A cotton ball soaked with isofurane was placed inside a plastic bag containing the bat and left inside to allow sufficient time for the anaesthetic gas to cause euthanasia. Alternatively, the bat was left in the sealed bag for sufficient time to achieve anaesthesia, at which time it was removed from the bag and injected intraperitoneally with an overdose of sodium pentobarbital. This finding is in agreement with the regulatory laws regarding experimental ethics of animal use and collecting permits, Institute of Animal Care and Use Committee (IACUC), protocol number CUFS/S/Para/36/14. Following dissection, trematodes were recovered from the intestine, immediately fixed and held in 10\% neutral buffered formalin for $48 \mathrm{~h}$, placed overnight in distilled water, stained overnight in acetocarmine, dehydrated in ethanol series, cleared in clove oil, and permanently mounted on glass slides using Canada balsam. Photomicrographs of stained whole mounted specimens were made with a Zeiss Axiovert 135 photomicroscope equipped with a PowerShot Canon digital camera. Drawings were made with the aid of a drawing tube. All measurements are presented in millimetres unless otherwise stated and are given as the range followed by the mean in parentheses. For scanning electron microscopy, specimens were fixed in $4 \%$ buffered glutaraldehyde, washed in cacodylate buffer, and dehydrated in alcohol. After passing through an ascending series of Genosolv-D, they were processed in a critical point drier "Bomer-900" with freon 13, sputter-coated with gold-palladium in a Technics Hummer V, and examined with an Etec Autoscan scanning electron microscope at $20 \mathrm{kV}$ Jeol.

\section{Results}

\section{MORPHOLOGICAL DESCRIPTION}

\section{Urotrema scabridum Braun, 1900}

Description ( $n=10)$ : Light microscopic examination (Figure 1a-c) showed that the parasite had an elongated body 1.50-2.22 $(2.06 \pm 0.02) \times 0.461-0.682(0.521 \pm 0.002) \mathrm{mm}$ (maximum width at its middle). The parasite's suckers were powerful and spaced at a distance of $1.2 \mathrm{~mm}$ apart, the oral sucker was $0.162-0.284$ $(0.19 \pm 0.002) \times 0.230-0.502(0.341 \pm 0.002) \mathrm{mm}$. An intestinal bifurcation occurred just underneath the oral suckers. Pharynx 0.021-0.33 $(0.026 \pm 0.002) \mathrm{mm}$ followed by oesophagus which 

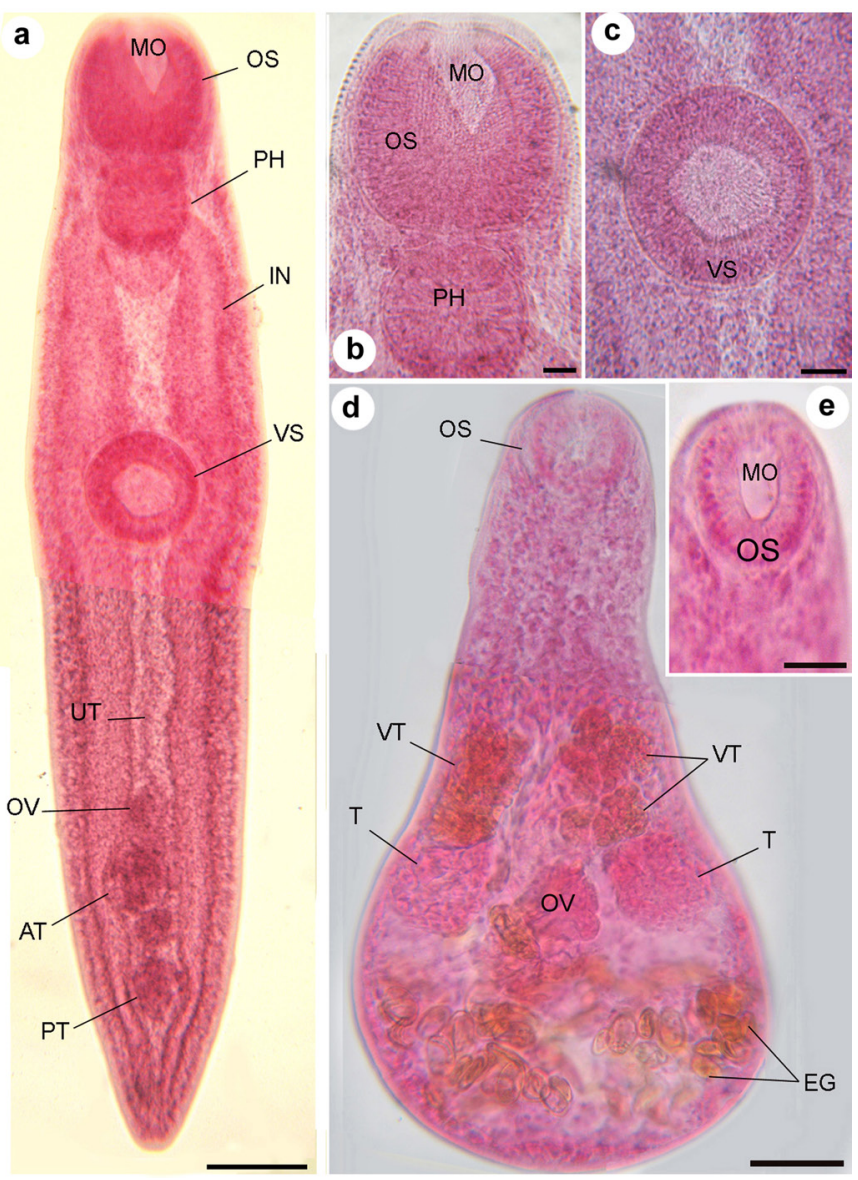

Figure 1. Photomicrographs of a-c: Urotrema scabridum; ventral view (a) Whole mount preparation, Bar $100 \mu \mathrm{m}$; (b) Terminal part of the worm, Bar $20 \mu \mathrm{m}$; (c) Ventral sucker, Bar $20 \mu \mathrm{m}$; d, e: Renschetrema indicum ventral view (d) Whole mount, Bar $100 \mu \mathrm{m}$; (e) oral sucker and the mouth opening, Bar $50 \mu \mathrm{m}$. OS, oral sucker; MO, mouth opening; PH, pharynx; IN, intestine; VS, ventral sucker; UT, uterus; OV, ovary; EG, eggs; AT, anterior testis; PT, posterior testis; VT, vitellaria, T, testis.

was $0.059-0.078(0.065 \pm 0.002) \mathrm{mm}$, the ventral sucker smaller, $0.171-0.232(0.213 \pm 0.002) \times 0.224-0.423(0.290 \pm 0.002) \mathrm{mm}$. Prepharynx very short. Testes tandem; anterior testis measured 0.101-0.193 (0.126 \pm 0.002$) \times 0.050-0.11(0.095 \pm 0.002) \mathrm{mm}$; posterior testis $0.112-0.271(0.153 \pm 0.002) \times 0.063-0.141$ $(0.155 \pm 0.002) \mathrm{mm}$. Vas deferens extended posteriorly from testes. The cirrus sac $0.133-0.312(0.243 \pm 0.002)$ long, contained a coiled seminal vesicle filling most of the cirrus sac; terminal portion of the seminal vesicle extended anteriorly on the dextral side, looping dorsally as the anterior cirrus; cirrus poorly developed. Ovary spherical located in front of the anterior part of testes,

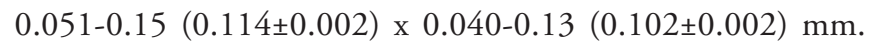
Ootype immediately posterior to the ovary. Mehlis' gland present and the Laurer's canal not observed. Seminal receptacle present, dorsal to the Mehlis' gland, vitelline follicles arranged in two lateral fields wrapped around the ceca. Eggs were 0.019-0.030 $(0.022 \pm 0.002) \mathrm{mm}$.
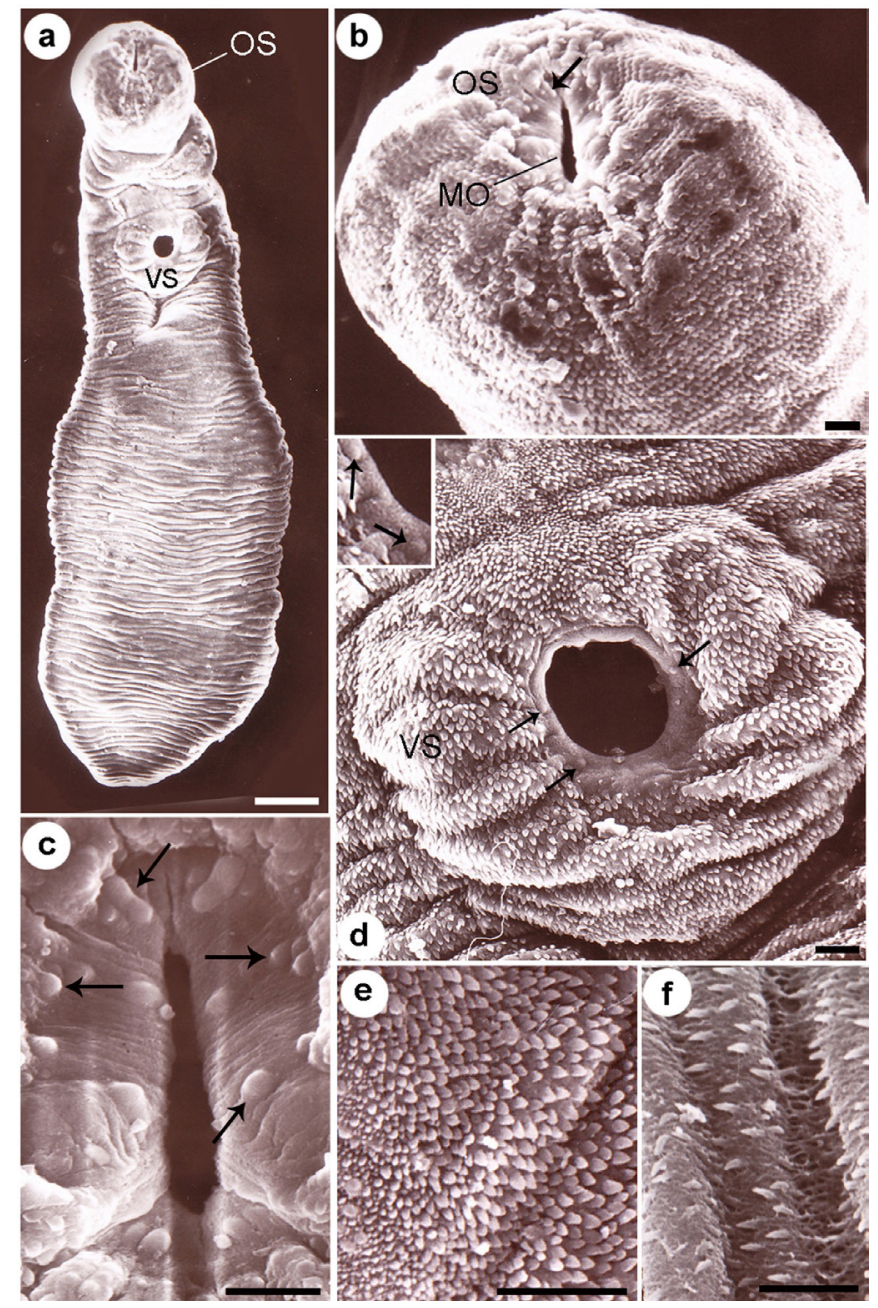

Figure 2. Scanning electron micrograph showing the surface topography of Urotrema scabridum. (a) Whole ventral view. OS, oral sucker; VS, ventral sucker, Bar $5 \mu \mathrm{m}$; (b) The terminal oral sucker with slit like mouth (MO) surrounded by papillae (arrow), Bar $20 \mu \mathrm{m}$; (c) type I dome like papillae (arrows) surrounding mouth, Bar $10 \mu \mathrm{m}$; (d) ventral sucker, the lip of this sucker was wrinkled and covered with tegument spines and few scattered papillae (arrows), magnified at the inset (arrows), Bar 10 $\mathrm{mm}$; (e) Tongue-shaped tegument spines below the level of the oral sucker, Bar 10 $\mu \mathrm{m}$; (f) Tegument between oral sucker and the ventral pit covered with pointed tip spines, Bar $5 \mu \mathrm{m}$.

SEM (Figure $2 \mathrm{a}-\mathrm{f})$ of the described parasite $(\mathrm{n}=5)$ showed that the anterior half of the body was covered by backwardly directed tegumental spines regularly arranged in rows and decreasing in number going posteriorly. The ventral pit was at the posterior level of the middle one-third of the body. The oral sucker contained a terminal mouth which was longer than its width. The lumen of the oral sucker was in the form of a longitudinal slit, and the lip was devoid of tegumental spines. The lumen of the ventral pit was covered with spines, which were smaller than those around the whole body. Two sizes of type I dome-shaped papillae encircled the lip of the oral sucker. The lip of the ventral sucker was wrinkled and covered by tegumental spines and few scattered papillae. A line diagram for the ventral view of the parasite holotype is illustrated in Figure 3. 


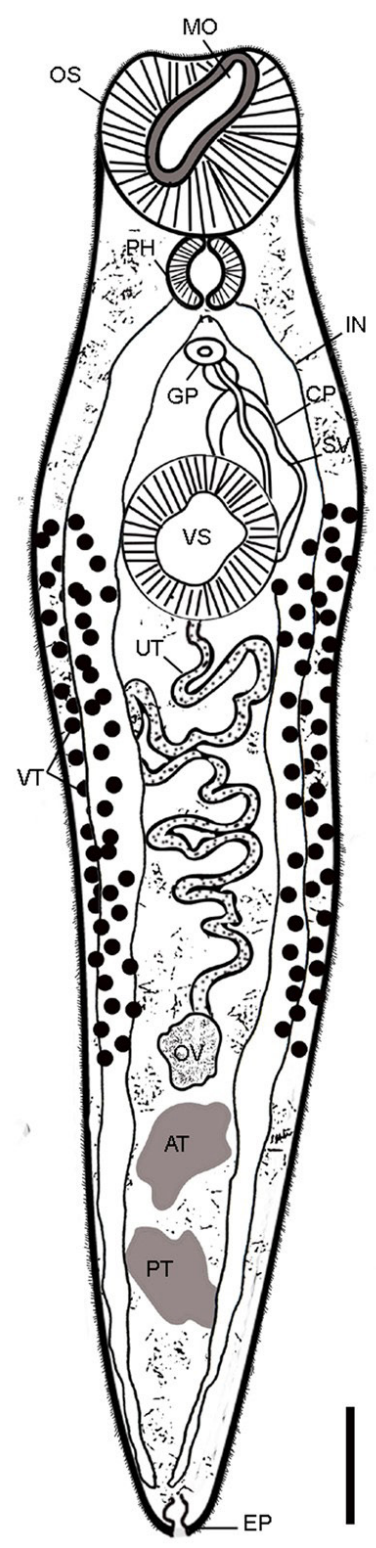

Figure 3. Urotrema scabridum; holotype ventral view; OS, oral sucker; $\mathrm{MO}$, mouth opening; $\mathrm{PH}$, pharynx; IN, intestine; VS, ventral sucker; OV, ovary; UT, uterus; AT, anterior testis; PT, posterior testis; GP, genital pore; SV, seminal vesicle; $\mathrm{CP}$, cirrus pouch; VT, vitellaria; EP, excretory pore, IN, intestine, Bar $100 \mu \mathrm{m}$.

\section{Remarks}

The recovered parasite possessed most of the morphological features characterizing the genus Urotrema: the terminal genitalia is at the posterior part of the body; tandem testes near the posterior end of the hind body; an ovary in the anterior hind body; unlobed gonads; and vitelline follicles extending anteriorly or anterior to the level of the ventral sucker. Compared with some of the previously reported species from different hosts, U. scabridum Braun, 1900 is the most closely similar species; both have ceca that extend posteriorly behind the posterior testis and the vitelline follicles do not extend to the level of the posterior margin of the pharynx. Minor differences that are observed in the morphometric data between the two species may be related to the effects of specimen preparation (Table 1).

\section{Taxonomic summary}

Family: Urotrematidae

Host: Egyptian lesser mouse-tailed bat Rhinopoma hardwickii. Locality: Attics of Egyptian buildings.

Infection site: Intestine.

Prevalence: four out of ten (40\%) were naturally infected with this parasite alone, while three specimens (30\%) showed a mixed infection with $R$. indicum.

Materials deposited: Parasitology division, Zoology department museum, Faculty of science, Cairo University, Egypt.

\section{Renschetrema indicum Kifune, 1984}

Description ( $\mathrm{n}=10)$ : Light microscopic examination (Figure 1d, e) showed that the body was usually fusiform, occasionally pyriform, 0.35-0.47 (0.42 \pm 0.02$) \times 0.23-0.41(0.391 \pm 0.002) \mathrm{mm}$ (maximum width at the posterior extremity); cuticular spines minute, dense and mostly distributed in the anterior part of the body; elongated subterminal oral sucker, 0.048-0.057 (0.512 \pm 0.002$)$

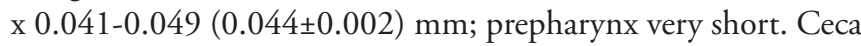
reached the anterior margin of ovary; the ventral sucker circular or elliptical, smaller than the oral sucker 0.039-0.052 (0.421 \pm 0.002$)$ x 0.0352-0.041 $(0.37 \pm 0.002) \mathrm{mm}$. Cirrus pouch long, strongly curved at the posterior third, latero-posterior to the ventral sucker; it was elliptically swollen with the seminal vesicle inside; testes sub-triangular and located at the posterior margin, laterally situated, and approached each other at the median line. The right testis was $0.056-0.082(0.071 \pm 0.002) \mathrm{mm}$ slightly longer than the left which was 0.050-0.075 $(0.063 \pm 0.002) \mathrm{mm}$. Ovary fusiform, latero-posterior to the seminal vesicle; seminal receptacle small, elliptical and dorso-posterior to the ovary. Vitellaria randomly distributed around ceca and genital organs; anterior follicles smaller than the posterior ones but densely compacted in the extracaecal region. Eggs were dark brown, elliptical and embryonated.

SEM (Figure 4a-e) of the described parasite $(n=5)$ showed that the fore body was ventrally concave, surrounded by cytoplasmic ridges equipped with numerous closely packed claw-shaped spines whose density decreased at the posterior extremity. As observed in all of the described specimens, the oral sucker and mouth opening were directed anteroventrally and externally surrounded by 12 papillae arranged as two circles ( 4 pairs located in the outer circle and 2 pairs located in the inner circle at each side of mouth). The ventral sucker was rounded and pre-equatorial, and its lip was surrounded by 5 papillae (3 located in the upper part of sucker and 2 located anterolateral, one at each side). Particular arrangements and variations in the morphology of spines were observed over the whole surface of the body, where the area around the oral and ventral sucker and in between contained tongue shaped tegumental spines differing from those around 
Table 1. Comparative measurements between U. scabridum and some species of the same genus recorded previously from different hosts.

\begin{tabular}{|c|c|c|c|c|c|}
\hline Type species & $\begin{array}{c}\text { U. minuta } \\
\text { Macy (1933) }\end{array}$ & $\begin{array}{l}\text { U. lasiiurensis } \\
\text { Alicata (1932) }\end{array}$ & $\begin{array}{c}\text { U. shirleyae } \\
\text { Zamparo et al. } \\
(2005)\end{array}$ & $\begin{array}{l}\text { U.scabridum } \\
\text { Braun (1900) }\end{array}$ & $\begin{array}{c}\text { U.scabridum } \\
\text { (present study) }\end{array}$ \\
\hline Host & $\begin{array}{l}\text { Lasionycteris } \\
\text { noctivagans }\end{array}$ & $\begin{array}{l}\text { Eptesicus fuscus, } \\
\text { Nycteris humeralis } \\
\text { Lasiurus borealis. }\end{array}$ & $\begin{array}{l}\text { Noropos cupreus } \\
\text { Noropos oxylophus }\end{array}$ & $\begin{array}{c}\text { Myotis levis } \\
\text { molossops teinckii } \\
\text { Tadarida brasiliensis. }\end{array}$ & Rhinopoma hardwickei \\
\hline Locality & United States & United States & Costa Rica & Brazil & Egypt \\
\hline $\begin{array}{l}\text { Total body } \\
\text { length }\end{array}$ & $1.98 \mu \mathrm{m}$ & $3-3.5$ & $\begin{array}{c}0.93-4.8 \\
(2.97)\end{array}$ & $\begin{array}{c}1.7-2.5 \\
(2.1)\end{array}$ & $1.50-2.22$ \\
\hline $\begin{array}{l}\text { Total body } \\
\text { width }\end{array}$ & - & $0.890-0.967$ & $\begin{array}{l}160-550 \\
(411) \mu \mathrm{m}\end{array}$ & $\begin{array}{c}360-450 \mu \mathrm{m} \\
(412)\end{array}$ & $0.461-0.682$ \\
\hline $\begin{array}{l}\text { Oral sucker } \\
\text { length }\end{array}$ & $116 \mu \mathrm{m}$ & $0.124-0.156$ & $\begin{array}{l}100-200 \\
(153) \mu \mathrm{m}\end{array}$ & $133-142 \mu \mathrm{m}$ & $0.162-0.284$ \\
\hline Ventral sucker length & $108 \mu \mathrm{m}$ & - & - & $\begin{array}{c}128-144 \mathrm{x} \\
134-152 \mu \mathrm{m}\end{array}$ & $0.171-0.232$ \\
\hline Anterior testis length & $188 \mu \mathrm{m}$ & $0.296-0.374$ & $\begin{array}{l}95-310 \\
(214) \mu \mathrm{m}\end{array}$ & $\begin{array}{c}128-323 x \\
134-285 \mu \mathrm{m}\end{array}$ & $0.101-0.193$ \\
\hline $\begin{array}{l}\text { Anterior testis } \\
\text { width }\end{array}$ & $264 \mu \mathrm{m}$ & $0.452-0.483$ & $\begin{array}{l}110-335 \\
(209) \mu \mathrm{m}\end{array}$ & - & $0.050-0.11$ \\
\hline $\begin{array}{l}\text { Posterior testis } \\
\text { length }\end{array}$ & $264 \mu \mathrm{m}$ & $0.343-0.405$ & $\begin{array}{l}112-300 \\
(234) \mu \mathrm{m}\end{array}$ & $\begin{array}{c}112-351 \mathrm{x} \\
122-323 \mu \mathrm{m}\end{array}$ & $0.112-0.271$ \\
\hline Posterior testis width & $236 \mu \mathrm{m}$ & $0.468-0.561$ & $\begin{array}{l}93-305 \\
(220) \mu \mathrm{m}\end{array}$ & - & $0.063-0.141$ \\
\hline Ovary length & $160 \mu \mathrm{m}$ & - & $\begin{array}{l}065-195 \\
(134) \mu \mathrm{m}\end{array}$ & $154-218 \mu \mathrm{m}$ & $0.051-0.15$ \\
\hline Ovary width & $208 \mu \mathrm{m}$ & - & $\begin{array}{c}60-185 \\
(129) \mu \mathrm{m}\end{array}$ & $112-209 \mu \mathrm{m}$ & $0.040-0.13$ \\
\hline
\end{tabular}

Measurements are in " $\mathrm{mm}$ ", otherwise stated.

the cytoplasmic ridges. A line diagram for the ventral view of the parasite holotype is illustrated in Figure 5.

\section{Taxonomic summary}

Family: Renschetrematidae Yamaguti, 1971

Host: Egyptian lesser mouse-tailed bat Rhinopoma hardwickii.

Locality: Attics of Egyptian buildings.

Infection site: Intestine.

Prevalence: three specimens out of ten (30\%) were infected with this parasite as a mixed infection with Urotrema scabridum.

Materials deposited: Parasitology division, Zoology department museum, Faculty of science, Cairo University, Egypt.

\section{Remarks}

This trematode is assigned to the genus Renschetrema (Microphallidae) according to the key published by Kifune (1984), which records only four species of this genus to date (Table 2). These species are Rohdetrema sandoshami Rohde, 1964 from Tylonycteris sp. and Kerivoula sp., Malaysia (Malay); Renschetrema malayi Rohde, 1964 from Rhinolophus sp. and Miniopterus juligino Kuala Senyul, Kelantan, Malay; and R. indicum Kifune, 1984 from Myotis nipalensis and M. muricola, West Bengal, West Sikkim India and Renschetrema sp. from Glischropus tylopus, Malaysia (Malay) (ROHDE, 1964). The present species differs from $R$. sandoshami in having an almost circular body, which is slightly broader than long; the vitellaria are extremely developed and distributed peripherally in contrast to the long body in the previously recorded parasite; it also differs from $R$. malayi whose two testes are remote from each other by at least a distance equal to their own breadth, while the testes are closely situated to each other in the present species. Renschetrema sp. differs by the presence of small vitelline follicles sparsely distributed in the preacetabular region in contrast to the large, compactly distributed vitelline follicles in the preacetabular region. However, the present parasite closely resembles $R$. indicum in most of the morphological features reported in the description of Kifune (1984) with some morphometric features somewhat less different.

\section{General organization of the tegument}

According to Halton \& Maule (2004), microscopy has providing fundamentally important information on the structural and functional correlates of a number of key organ systems of helminths, such as their body surface. Detailed studies on the ultrastructural characteristics of digeneans can provide useful information in the taxonomic study of the groups. There are no existing records describing the surface topography and the ultrastructural characteristics of the tegument for the two species described herein.

The tegument organization of the two species is similar to the general tegument structure described for digeneans studied previously (MORRIS \& THREADGOLD, 1968; BENNETT \& 

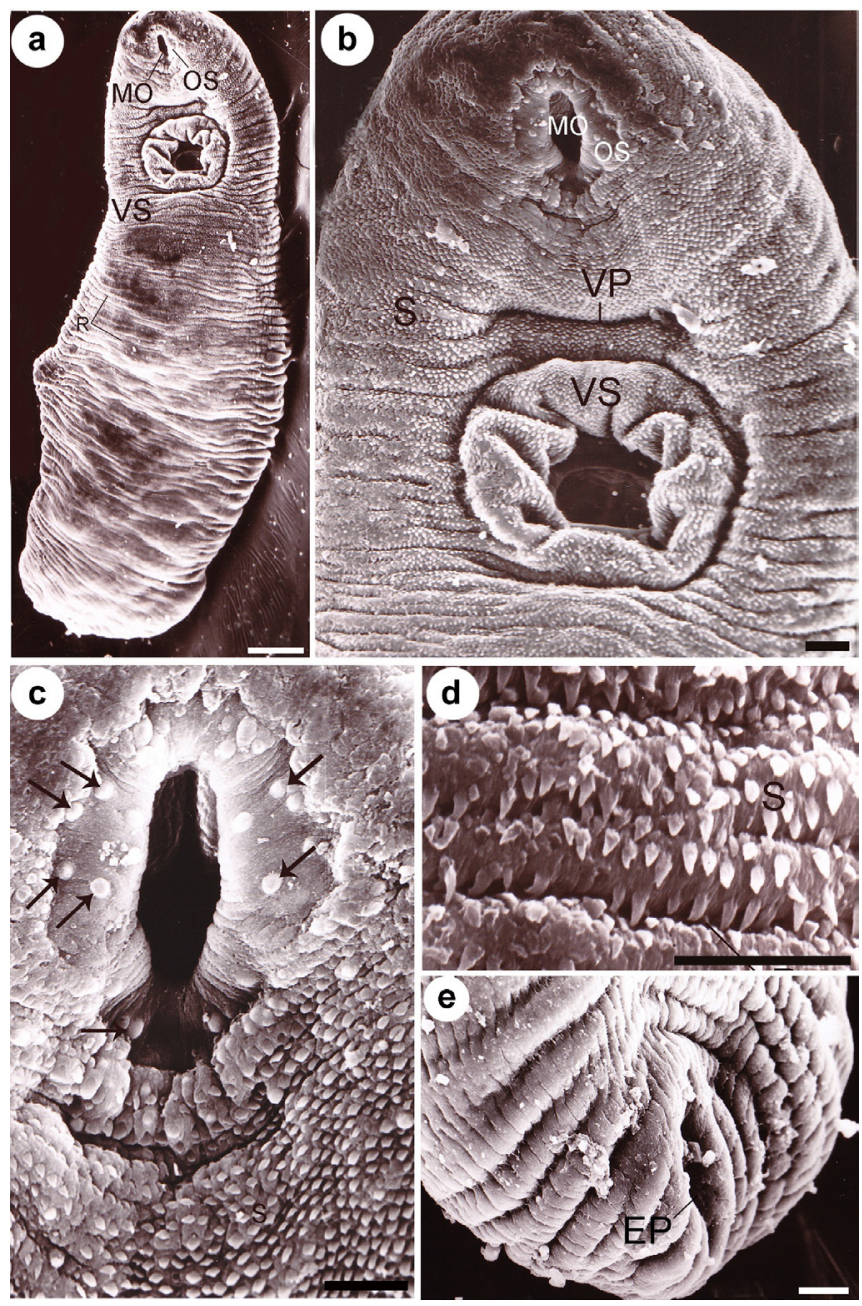

Figure 4. Scanning electron micrograph showing the surface topography of Renschetrema indicum. (a) Whole ventral view; OS, oral sucker; MO, mouth opening; VS, ventral sucker; R, cytoplasmic ridges, Bar $20 \mu \mathrm{m}$; (b) The anterior half of the worm, oral sucker includes the mouth opening which is directed anterioventrally and surrounded by papillae, the ventral sucker is pre-equatorial, VP ventral pit; $S$ tegument spines, Bar $5 \mu \mathrm{m}$; (c) Terminal portion of the body showing the oral sucker with two circles of papillae (arrows) surrounding the mouth opening, Bar $10 \mu \mathrm{m}$; (d) Tegument ridges equipped with rows of spines with pointed tip, Bar $10 \mu \mathrm{m}$; (e) The posterior extremity, devoid of spines, with the sub-terminal excretory pore (EP), Bar $10 \mu \mathrm{m}$.

THREADGOLD, 1975; THREADGOLD, 1984; ROBERTS \& JANOVY, 2000). Folds in the tegument such as cytoplasmic ridges on the body surface and cobblestone-like zones could participate in nutrition by amplifying the free surface area (PAPERNA \& DZIKOWSKI, 2006). Cytoplasmic ridges of the tegument have also been observed in SEM micrographs of other digeneans, such as Bucephalus anguillae (FILIPPI et al., 2010), Fasciola hepatica (BENNETT, 1975), Lecithochirium musculus (FILIPPI et al., 2012), and Schistosoma mansoni (HOCKLEY, 1973). In the present study, spines surrounding the body and suckers were of different shapes within parasite species, being either tongue- or claw-shaped, which agrees with the study of Lee et al. $(1985,1987)$ who concluded

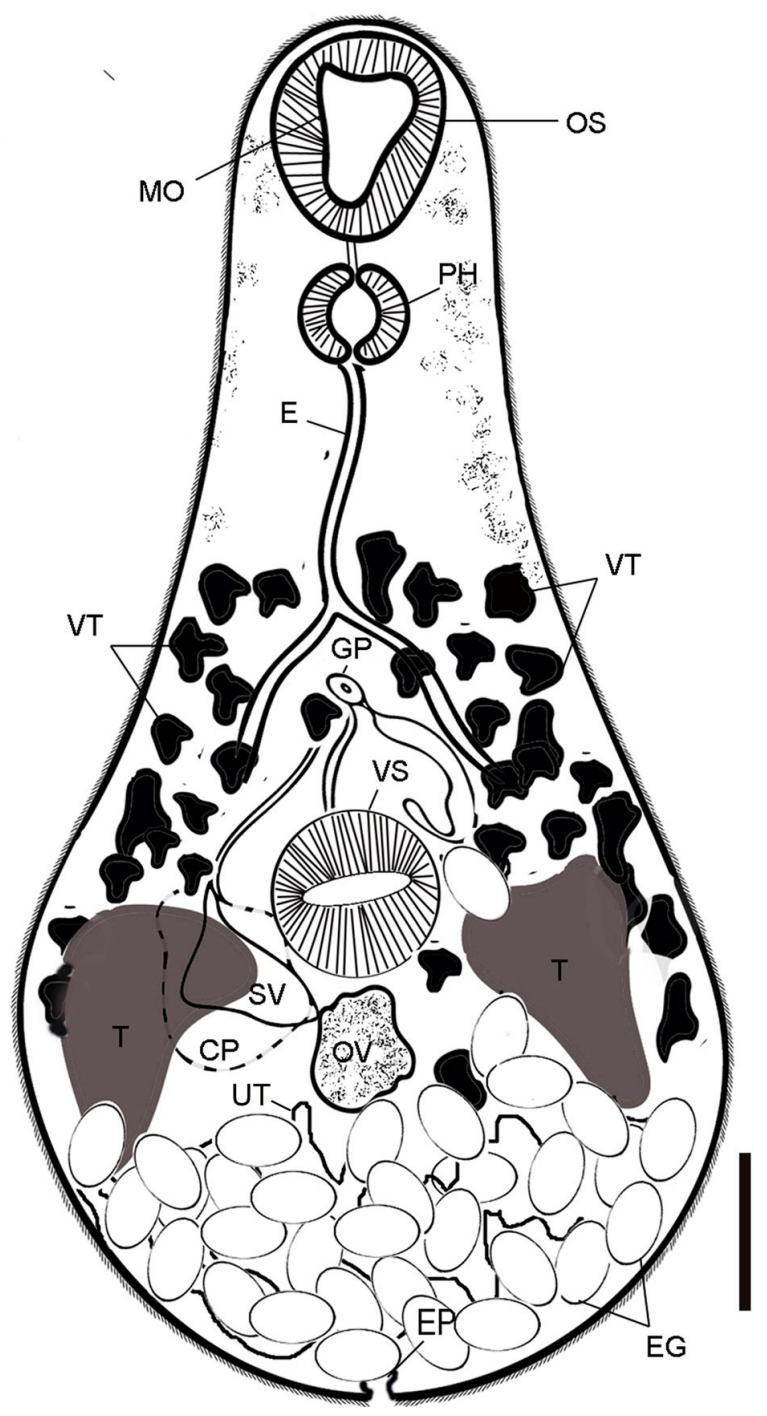

Figure 5. Renschetrema indicum; holotype ventral view; OS, oral sucker; MO, mouth opening; $\mathrm{PH}$, pharynx; E, esophagus; VS, ventral sucker; OV, ovary; UT, uterus; EG, eggs; T, testis; GP, genital pore; SV, seminal vesicle; CP, cirrus pouch; VT, vitellaria; EP, excretory pore, Bar $50 \mu \mathrm{m}$.

that the tegument spines have shapes and distributions that vary between parasite species, and these are related to the size or shape of worms and their migration pattern. This difference may also involve a significant difference in host-parasite relationships (CHAI et al., 2000). Køie (1977) suggested that large, pointed spines may be involved in feeding, with spines acting as abrasive structures for the host tissue. In contrast, Senft et al. (1961) and Lumsden (1975) opined that spines aided in the attachment to the host tissue. Several authors have also argued that spines could be involved in locomotion (BENNETT, 1975; URSONE \& FRIED, 1995). The decrease in spine density on the non-feeding sucker (the oral sucker) may be related to a specialization of the area which facilitates attachment to the host tissue without causing damage (PANDEY \& TEWARI, 1984). As in the present study, Dezfuli et al. (1997) also observed a decrease in spine density in 
Table 2. Comparative measurements between $R$. indicum and some species of the same genus recorded previously from different hosts.

\begin{tabular}{|c|c|c|c|c|c|}
\hline Type species & $\begin{array}{c}\text { R.indicum } \\
\text { Kifune (1984) } \\
\end{array}$ & $\begin{array}{l}\text { R. sandoshami } \\
\text { Rohde (1964) }\end{array}$ & $\begin{array}{c}\text { R. malayi } \\
\text { (Rohde 1964) }\end{array}$ & $\begin{array}{c}\text { Renschetrema sp. } \\
\text { (Rohde 1964) }\end{array}$ & $\begin{array}{c}\text { R.indicum } \\
\text { (present study) }\end{array}$ \\
\hline Host & $\begin{array}{l}\text { Myotis nipalensis } \\
\text { Myotis muricola }\end{array}$ & $\begin{array}{l}\text { Tylonycteris sp. } \\
\text { Kerivoula sp. }\end{array}$ & $\begin{array}{c}\text { Rhinolophus sp. } \\
\text { Miniopterus juligino }\end{array}$ & Glischropus tylopus & Rhinopoma hardwickei \\
\hline Locality & $\begin{array}{l}\text { West Bengal, West Sik- } \\
\text { kim India. }\end{array}$ & Malaysia (Malay) & $\begin{array}{l}\text { Kuala Senyul, Kelan- } \\
\text { tan, Malay }\end{array}$ & Malaysia (Malay) & Egypt \\
\hline Total body length & $0.36-0.44$ & $\begin{array}{l}0.44-0.53 \\
0.48\end{array}$ & $0.32-0.47$ & 0.42 & $0.35-0.47$ \\
\hline Total body width & $0.22-0.27$ & $\begin{array}{l}0.445-.57 \\
0.51\end{array}$ & $0.24-0.37$ & 0.19 & $0.23-0.41$ \\
\hline Oral sucker & $\begin{array}{l}0.056-0.063 \mathrm{x} \\
0.047-0.056\end{array}$ & $\begin{array}{c}0.090 \times 0.120-0.120 \\
\times 0.129\end{array}$ & $0.047-0.026$ & $0.039 \times 0.042$ & $0.048-0.057$ \\
\hline Pharynx & $0.025-0.030$ & $\begin{array}{c}0.039 \times 0.033- \\
0.048 \times 0.031\end{array}$ & $\begin{array}{l}0.029 \times 0.026- \\
0.032 \times 0.047\end{array}$ & $0.016 \times 0.024$ & $0.021-0.33$ \\
\hline Ventral sucker & $\begin{array}{c}0.050-0.053 \mathrm{x} \\
0.045-0.050\end{array}$ & $\begin{array}{l}0.100 \times 0.100- \\
0.123 \times 0.129\end{array}$ & $\begin{array}{l}0.039 \times 0.045- \\
0.054 \times 0.054\end{array}$ & $0.036 \times 0.036$ & $0.039-0.052$ \\
\hline Oseophagus & - & - & $0.060-0.0960 .083$ & - & $0.059-0.078$ \\
\hline Right testis & $\begin{array}{c}0.068-0.075 \mathrm{x} \\
0.100-0.122\end{array}$ & - & $0,078 \times 0,040$ & - & $0.056-0.082$ \\
\hline Left testis & $\begin{array}{c}0.060-0.094 \mathrm{x} \\
0.120\end{array}$ & - & - & - & $0.050-0.075$ \\
\hline Ovary length & - & $0.123-0.150$ & $0.030-0.041$ & $0.042 \times 0.066$ & $0.036-0.070$ \\
\hline Ovary width & & $0.075-0.120$ & $0.086-0.140$ & - & $0.050-0.076$ \\
\hline Egg & $\begin{array}{c}0.032-0.036 \\
\mathrm{x} 0.020-0.024\end{array}$ & $\begin{array}{l}0.027-0.30 \mathrm{x} \\
0.018 \\
\text { average } 0.021\end{array}$ & $\begin{array}{l}0.025-0.30 \mathrm{x} \\
0.16\end{array}$ & $\begin{array}{c}0.024-0.026 \mathrm{x} \\
0.014-0.015\end{array}$ & $0.019-0.030$ \\
\hline
\end{tabular}

the ventral part of the small portion between the two suckers, while the lateral spines of this region are larger and stockier than any other spine observed on the entire body surface. The presence of domed papillae in the region of the oral sucker is frequently recorded in digeneans. The domed papillae are smooth, without apical cilia as in Calicophoron sp. and Erilepturus hamati reported in the studies of Tandon \& Maitra (1982) and Abdou (2001), respectively; and not vesicular with a granular appearance as in Dicrocoelium dendriticum (CIFRIAN et al., 1988). These papillae may help in tactile and receptive functions (BENNETT, 1975; OTUBANJO, 1985). Both of the parasite species recovered in the present study showed a thick-lipped ventral sucker and papillae with intertwining folds; these folds and papillae help in creating a strong attachment to the host surface (TANDON \& MAITRA, 1983).

\section{Acknowledgements}

The authors would like to express their gratitude to King Khalid University, Saudi Arabia for providing administrative and technical support. Additionally, authors extend their appreciation to the Faculty of Science, Cairo University, Cairo, Egypt.

\section{References}

Abdou NS. Surface topography of Erilepturus hamati Manter, 1947 (Digenea, Family: Hemiuridae) by scanning electron microscopy. J Egypt Soc Parasitol 2001; 31(1): 199-212. PMid:12557943.
Alicata JE. A new trematode of the genus Urotrema from bats. Proc US Nat Mus 1932; 81: 1-4. http://dx.doi.org/10.5479/si.00963801.81-2928.1.

Baer JG. Trématodes et Cestodes récoltés en Côte d'Ivoire, avec remarques sur la famille des Dicrocoeliidae Odhner et sur les parasites des Damans. Rev Suisse Zool 1957; 64: 547-575. http://dx.doi.org/10.5962/bhl.part.75502.

Bennett CE. Surface features, sensory structures, and movement of the newly excysted juvenile Fasciola hepatica L. J Parasitol 1975; 61(5): 886891. http://dx.doi.org/10.2307/3279229. PMid:1185430.

Bennett CE, Threadgold LT. Fasciola hepatica: development of tegument during migration in mouse. Exp Parasitol 1975; 38(1): 38-55. http:// dx.doi.org/10.1016/0014-4894(75)90036-3. PMid:1149868.

Braun M. Trematoden der Chiroptera. Annal Nat Mus Wien 1900; 15: 217-236.

Burton RF. Aspects of ionic regulation in certain terrestrial pulmonata. Comp Biochem Physiol 1966; 17(3): 1007-1018. http://dx.doi.org/10.1016/0010406X(66)90139-3. PMid:5943903.

Caballero CE, Zerecero C. Trematches of murciélagos of Mexico II: redescription and systematic positioning of Distomum tubiporum Braun, 1900. Ann Inst Biol 1942; 13: 97-104.

Chai JY, Guk SM, Han ET, Seo M, Shin EH, Sohn WM, et al. Surface ultrastructure of Metagonimus takahashii metacercariae and adults. Korean J Parasitol 2000; 38(1): 9-15. http://dx.doi.org/10.3347/kjp.2000.38.1.9. PMid:10743353.

Cifrian BS. Martinez-Allos S, Garcia-Corrales P. Ultrastructural study of spermatogenesis and mature Bothromesostom personatum (Rhabdo coela), typhoplanoida). Fortschr Zool 1988; 36: 309-314. 
Dezfuli BS, Nestorov M, Kanev I, Fied B. Scanning electron microscopy of the tegumentary spines of Deropristis inflata and Pseudechinoparyphium echinatum (Trematoda). Comp Rend Acad Bulg Scis 1997; 50(7-8): 81-84.

Filippi JJ, Quilichini Y, Foata J, Marchand B. Topography and ultrastructure of the tegument of Bucephalus anguillae (Digenea: Bucephalidae), a parasite of the European eel Anguilla anguilla (Osteichthyen: Anguillidae). J Parasitol 2010; 96(6): 1102-1111. http://dx.doi.org/10.1645/GE-2498.1. PMid:21158617.

Filippi JJ, Quilichini Y, Foata J, Marchand B. Topography and ultrastructure of the tegument of Lecithochirium musculus (Digenea: Hemiuridae), a parasite of the European eel Anguilla anguilla (Osteichthyes: Anguillidae). JMorphol2012; 273(4):361-370. http://dx.doi.org/10.1002/jmor.11032. PMid:22109611.

Halton DW, Maule AG. Flatworm nerve-muscle: structural and functional analysis. Can J Zool 2004; 82(2): 316-333. http://dx.doi.org/10.1139/ z03-221.

Hockley DJ. Ultrastructure of the tegument of Schistosoma. Adv Parasitol 1973; 11(0): 233-305. http://dx.doi.org/10.1016/S0065-308X(08)60188-8. PMid:4366409.

Kifune T. Trematoda of some Indian bats with description of a new Renschetrema (Digenea, Microphallidae). Bull Nat Sci Mus 1984; 10(4): 159-163.

Køie M. Stereoscan studies of cercariae, metacercariae, and adults of Cryptocotyle lingua (Creplin, 1825) Fischoeder 1903 (Trematoda: Heterophyidae). J Parasitol 1977; 63(5): 835-839. http://dx.doi. org/10.2307/3279888. PMid:915613.

Lee SH, Hong SJ, Chai JY, Seo BS. Studies on intestinal trematodes in Korea: XV. Tegumental ultrastructures of Fibricola seoulensis according to developmental stages. Seoul J Med 1985; 26(1): 52-63.

Lee SH, Sohn WM, Hong ST. Scanning electron microscopical findings of Echinochasmus japonicus tegument. Korean J Parasitol 1987; 25(1): 51-58. http://dx.doi.org/10.3347/kjp.1987.25.1.51. PMid:12886082.

Lumsden RD. Surface ultrastructure and cytochemistry of parasitic helminths. Exp Parasitol 1975; 37(2): 267-339. http://dx.doi.org/10.1016/00144894(75)90078-8. PMid:164363.

Macy RW. A review of the trematode family Urotrematidae with the description of a new genus and two new species. Trans Am Microsc Soc 1933; 52(3): 247-254. http://dx.doi.org/10.2307/3222260.

Mane-Garzon F, Telias D. Un nuevo trematodo del genero Urotrema de la rata de agua y redescipcion de Urotrema scabridum Braun, 1900. Comunic Zool Mus Hist Nat Montevideo 1965; 8: 1-9.

Mata-López R, Leon-Regagnon V. Comparative study of the tegumental surface of several species of Gorgoderina Looss, 1902 (Digenea: Gorgoderidae), as revealed by scanning electron microscopy. Comp Parasitol 2006; 73(1): 24-34. http://dx.doi.org/10.1654/4186.1.

Morris GP, Threadgold LT. Ultrastructure of the tegument of adult Schistosoma mansoni. J Parasitol 1968; 54(1): 15-27. http://dx.doi. org/10.2307/3276867. PMid:4170893.

Otubanjo OA. Scanning electron microscopic studies of the body surface and external genitalia of a dicrocoeliid trematode, Concinnum epomopis
Sandground 1973. Z Parasitenkd 1985; 71(4): 495-504. http://dx.doi. org/10.1007/BF00928352.

Pandey KC, Tewari SK. SEM studies on Bucephalopsis karvei Bhalerao, 1937, an intestinal parasite of the fish, Xenentodon cancila (Ham.). Proc Indiana Acad Sci 1984; 93(6): 527-533. http://dx.doi.org/10.1007/ BF03186301.

Paperna I, Dzikowski R. Digenea (Phylum: Platyhelminthes). In: Woo PTK, editor. Fish diseases and disorders: protozoan and metazoan infection. 2nd ed. Wallingford: CAB international; 2006. p. 345-390. (vol. 1).

Perez-Vigueras I. Notas sobre algunas especies nuevas de trematodos y sobre otros poco conocidos. Rev Univ Habana 1940; 28y(29): 1-28.

Poche F. Das system der Platodaria. Arch Naturgesch 1926; 91: 1-458.

Price EW. Four new species of trematode worms from the muskrat, Ondatra zibethica, with a key to the trematode parasites of the muskrat. Proc US Nat Mus 1931; 79: 1-13.

Roberts LS, Janovy J Jr. Foundations of parasitology. 6th ed. Dubuque: McGraw-Hill; 2000. 670 p.

Rohde K. Eine neue Trematodengattung (Renschetrema, Microphallidae) mit drei Arten aus dem Darm malayischer Fledermäuse. Z Parasitenkd 1964 24(1): 13-22. http://dx.doi.org/10.1007/BF00260419. PMid:14174780.

Saoud MFA, Ramadan MM. Studies on the helminth parasites of bats in Egypt and the factors influencing their occurrence with particular reference to digenetic trematodes. Z Parasitenkd 1976; 51(1): 37-47. http://dx.doi.org/10.1007/BF00380527.

Senft AW, Philpott DE, Pelofsky AH. Electron microscope observations of the integument, flame cells, and gut of Schistosoma mansoni. J Parasitol 1961; 47(2): 217-229. http://dx.doi.org/10.2307/3275292. PMid:13750088.

Tandon V, Maitra SC. Scanning electron microscopic observations on the tegumental surfaces of two rumen flukes (Trematoda: Paramphistomata). J Helminthol 1982; 56(2): 95-104. http://dx.doi.org/10.1017/ S0022149X00034295. PMid:7096975.

Tandon V, Maitra SC. Surface morphology of Gastrodiscoides hominis (Lewis \& McConnell, 1876) Leiper, 1913 (Trematoda: Digenea) as revealed by scanning electron microscopy. J Helminthol 1983; 57(4): 339342. http://dx.doi.org/10.1017/S0022149X00011056. PMid:6668422.

Threadgold LT. Parasitic platyhelminths. In: Bereiter-Hahn J, Matoltsy AG, Richards KS, editors. Biology of the integument: iInvertebrates. Berlin: Springer; 1984. chapt. 11, p. 132-191. (vol. 1). http://dx.doi. org/10.1007/978-3-642-51593-4_11.

Ursone RL, Fried B. Light and scanning electron microscopy of Echinostoma caproni (Trematoda) during maturation in ICR mice. Parasitol Res 1995 81(1): 45-51. http://dx.doi.org/10.1007/BF00932416. PMid:7724513.

Wimsatt W. Biology of bats. New York: Academic Press; 1970. (vol. 1).

Zamparo D, Brooks DR, Tkach V. Urotrema shirleyae n. sp. (Trematoda: Digenea: Urotrematidae) in Norops oxylophus and N. cupreus (Squamata: Iguania: Polychrotidae) from the area de Conservación Guanacaste, Costa Rica. J Parasitol 2005; 91(3): 648-652. http://dx.doi.org/10.1645/GE3341. PMid:16108560. 